\title{
ENCYCLOPADIA IRANICA
}

\author{
EDITED BY \\ EHSAN YARSHATER \\ Center for Iranian Studies \\ Columbia University \\ New York
}

Volume VI

FASCICLE 3

CONTRACTS III-COTTON II

\section{Mazda Publishers \\ Costa Mesa, California}

1992 
charcoal; Safavid chefs, for instance, used this method (Bāvarčì, pp. 183-84; Nūr-Allāh, p. 198). Because of its complexity baking was not as common in the preparation of Persian foods in the past as it is today. Recently, however, there has been a tendency to bake some dishes, like $k \bar{u} k \bar{k}$ s, that were traditionally fried, browned, or steamed on the stove or over an open fire.

Seasoning is usually moderate; salt, black pepper, turmeric, saffron, cinnamon, and marjoram are the most common spices and flavorings. In contrast to the practice in some parts of India, fiery seasonings are rarely used in Persian cuisine and then only sparingly. The subtle flavor and aroma of herbs like dill, mint, coriander, parsley, and fenugreek are preferred. A good cook is distinguished by the ways in which he or she blends them.

Presentation of foods is also important, and wellprepared Persian dishes are as attractive to the eye as to the palate. Asses, halims, and other dishes are topped with golden-brown onions, nuts, saffron-colored ingredients, and yogurt or cheese in intricate patterns. Polows and čelows are usually served on large platters and decorated with a handful of saffron rice and perhaps other ingredients.

Bibliography: A. 'Abd-al-Hosaynzăda, Barrasi-e masā'el-e eqteșād-e kešàvarzi-e Irān, Tehran, 1365 \./1986. İ. Afśăr, Ǎspazi-e dawra-ye șafawi. Matne do resāla az än dawra, Tehran, 1360 S./1981. N. Batmanghelij, Food of Life, Washington, D.C., 1986. Mohammad-'Alī Bāvarči Bağdādí, Kär-nāma dar bāb-e tabbākiki wa san'at-e än, in İ. Afšăr, ed., Ašpazie dawra-ye safawi. Matn-e do resāla az ān dawra, Tehran, 1360 S./1981, pp. 35-184. M. R. Ghanoonparvar, Persian Cuisine, 2 vols., Lexington, Ky., 1982-84. F. Hekmat, The Art of Persian Cooking, Garden City, N.Y., 1961. N. Islami, Persian Cookery, n.p., n.d. T. Mallos, "Persia," in Complete Middle East Cookbook, New York, 1979, pp. 293-336. M. Mazda, In a Persian Kitchen. Favorite Recipes from the Near East, Rutland, Vt., 1960; repr. Rutland, Vt., 1980. Mirză 'Alī-Akbar Khan ĀŚpazbăši, Sofra-ye at' 'ema, Tehran, 1353 S./ 1974. A. Mìrzāyef, Abū Eshāa wa fa"cälìyat-e adabie $\bar{u}$, Dushanbe, 1971. R. Montazamì, Majmü'a-ye

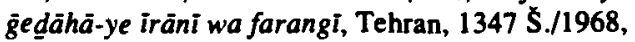
pp. 517-18. H. Nickles, Middle Eastern Cooking, New York, 1969, pp. 8-41, 152-75. Nūr-Allāh, Māddat al-hayāt. Resāla dar 'elm-e tabbākīi, in İ. Afšâr, ed., Asśpazi-e dawra-ye Safawi. Main-e do resāla az än dawra, Tehran, 1360 S./1981, pp. 185256. N. Ramazani, Persian Cooking. A Table of Exotic Delights, Charlottesville, Va., 1982, pp. 7175. E. Šakūrzăda, 'Aqāyed o rosūm-e mardom-e Korāsān, Tehran, 1363 S./1984, pp. 23-76. M. Tehrāni; Tabbāki-e kadbānū, Tehran, 1346 S./1967. A. Yãvarî, Moqaddama-i bar šenāklı-e kešāvarzi-e sonnari-e Irän, Tehran, 1359 Š./1980. H.. Yūsofí, Räh-e del, Tehran, 1360 S./1981.

(Mohammad R. Ghanoonparvar)

\section{iv. In Afghanistan}

Various traditions pertaining to Afghan cookery form an integral part of the deeply entrenched Afghan social institution of hospitality. Family honor, as well as individual status within the community, is measured in good part by the lavishness of the household kitchen. All events in the life cycle from birth to death, as well as changes of season, are celebrated with feasting (Tapper).

Although regional culinary specialties reflect the geographic and ethnic diversity of Afghanistan and affinities with the cuisines of Central Asia, Persia, and Pakistan (Bacon, passim; L. Dupree, 1980, pp. 225-38; N. H. Dupree, 1977, pp. 9-10), the daily diet of the majority of Afghans is simple, consisting primarily of bread and generous amounts of sugared tea, black or green, with or without cardamom. Only in rare instances is tea drunk with milk (see Č́̃Y).

Bread (nän) is made in various shapes and sizes and may be leavened or unleavened; the flour may be of wheat, barley, com, lentils, or millet. Bread is sometimes baked on the walls of a clay oven (tandūr, tanūr) set into a mud-brick platform (Jeanneret, pp. 37-44). A convex iron griddle set on a tripod over an open fire is the method preferred by many nomadic groups. Shepherds wrap dough around hot rocks and set it to bake beside the campfire (L. Dupree, 1980, pp. 225-27; Wannell, p. 22). However it is prepared, nän is so central to the diet that the term refers to food in general throughout Afghanistan, as in Persia (cf. BREAD).

On festive occasions the main dish usually consists of a mounded platter of rice (see BERENJ ii). Rice cooked with large chunks of lamb or chicken (pelaw, polow) and plain boiled rice (čalaw, čelow), somerimes mixed with chopped spinach (sabzi pālak) and aptly called zamarod or zomorrod "emerald" pelaw, are particularly popular. Meat and vegetables may al so be served in various forms of stew (qürmalqorma), with rice or bread on the side. Some provincial teahouses specialize in čăynaki, meat stews cooked in teapots ( $\breve{a}$ ynnak) embedded in hot coals.

"Kabob" (kabāb) is a collective term for at least seven varieties of lamb dish served with bread, which are considered great delicacies. When charcoal-broiled on skewers known as sik, kabobs may consist of small cubes of lamb marinated in yogurt with garlic and threaded on the skewers in alternation with pieces of fat, large meaty chunks with bone fragments attached, or minced meat in oblong patties molded around the skewer. Other dishes based on cubed or minced lamb, also called kabäb, may be pan-fried or baked in heavy iron utensils (Saberi, pp. 71-80; N. H. Dupree, 1972, pp. 160-61). Game birds are roasted, stewed, panfried, or charcoal-broiled. Steamed meat dumplings (mantü) are a specialty of cooks in the north.

Pasta dishes (L. Dupree, 1983) are also favorites; they range from soups containing noodles, legumes

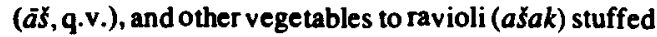
with cheese or Chinese chives (gandana/gandanā) and topped with a tomato-based meat sauce. Most 
such dishes are topped with drained yogurt (čaka) or the more acidic qorüti, made by reconstituting rockhard dehydrated balls of čaka (qorūt) in water (see CHEESE). A slightly sweetened pelaw flavored with turmeric, orange peel, almonds, and pistachio nuts is often served as an accompanying dish.

Traditionally the main cooking oils were clarified butter, or ghee, and lard rendered from the tails of fattailed sheep, but in the 1960 s lighter vegetable oils were introduced and are widely used. A great variety of herbs and spices, including cumin, coriander, mint, cinnamon, cloves, and sesame, are used in cooking; chili peppers are, however, used only sparingly. Herbs and spices are also believed to have a wide variety of medicinal properties, especially in aiding digestion (Parenti, passim).

Pickled vegetables (tor $̌ \bar{i})$; chutneys (čotni $)$ made from red peppers, coriander, or fruits; and salads of chopped tomato, onion, fresh coriander, and lime juice typically accompany meals (Saberi, p. 123). The fresh juice of sour oranges heightens the flavor of pelaw, while skewered kabäbs are most often sprinkled with crushed dried grape seeds and red and black pepper. Nuts, raisins, and carrots are also often used as garnishes (L. Dupree, 1983, pp. 227-31).

Qorüti reconstituted with oil is popular eaten with bread in winter; a dish of eggplant and čaka is a particular favorite at any time (bānjan-e būrānì) bädenjān-e büränī). Other products made from cow's, sheep's, and goat's milk include yogurt (māst) and buttermilk ( $d \bar{u} \bar{g}, q . v$.), to which diced cucumbers are added in summer. A soft, unpasteurized cheese commonly served with raisins is a springtime specialty ( $\mathbf{N}$. H. Dupree, 1977, p. 196). Butter is churned in inflated goatskins and clarified into ghee (Strand, pp. 127-28). A rich, clotted cream (qaymāq) is eaten with bread for breakfast (L. Dupree, 1980, p. 235) and on special occasions is also served as an elegant topping for tea.

Crisp fried pastries made from bread and stuffed with gandana or mashed potatoes (büläni) are frequently served as appetizers or as part of the main meal. Sugarcoated chickpeas, apricot kernels, pistachio, walnuts, and almonds, collectively known as noql, as well as raisins and other dried fruits, are served with tea and before meals. A mix of walnuts and dried mulberries (čokida) and hard bars of ground mulberries (talkān) provide nutritious snacks, often carried by travelers (N. H. Dupree, 1977, p. 116).

Seasonal fruits, the most important being melons, grapes, apricots, plums, cherries, and peaches, are commonly served at the end of the meal, but festive occasions call for specialties. A compote made from seven fruits and nuts (haft-meywa, haft-miva) is served at celebrations of the New Year on 1 Nowrüz/21 March, the first day of spring; another popular dish at such festivities is fish followed by crisp pastries soaked in sugar syrup (jalabì). One elaborate, and ancient, dish is reserved for weddings and similar ceremonial occasions; it is composed of gossamer strands of egg batter quickly deep-fried in hot oil and laced with sugar syrup (abrēšom- or abrišam-kabāb, lit. "silk kabob"; L. Dupree, 1983, pp. 235-36; Saberi, pp. 128, 144).

The distribution of food, particularly sweets, as a symbolic gesture of thanksgiving plays a significant part in domestic religious rituals (Doubleday, pp. 49 53) and in acknowledging answered prayers (Saberi, p. 22). Affluent pilgrims to religious shrines publicly distribute massive quantities of pelaw to the needy and faithful in gratitude for boons granted. Many shrines maintain mammoth cooking vessels and a staff of male cooks especially for this purpose (N. H. Dupree, 1977 , p. 307).

Bibliography: E. Bacon, Central Asians under Russian Rule, Ithaca, N.Y., 1966. V. Doubleday, Three Women of Herat, London, 1988. L. Dupree, Afghanistan, Princeton, N.J., 1980. Idem, "From Whence Cometh Pasta?" in P. Snoy, ed., Ethnologie und Geschichte. Festschrift für Karl Jettmar, Wiesbaden, 1983, pp. 128-34. N. H. Dupree, Kabul, 2nd ed., Kabul, 1972. Idem, An Historical Guide to Afghanistan, 2nd ed., Kabul, 1977. A. Jeanneret, "Contribution à l'étude des boulangers de Kaboul," Afghanistan Journal (Graz) 1/2, 1974, pp. 37-44. C. Parenti, A Taste of Afghanistan. The Cuisine of the Crossroads of the World, Phoenix, Ariz., 1987. H. Saberi, Noshe Djan, London, 1986. M. Nazif Shahrani, The Kirghiz and Wakhi of Afghanistan, Seattle, Wash., 1979. P. Shalizi, Here and There in Afghanistan, Kabul, 1966. R. Strand, "The Changing Herding Economy of the Kom Nuristani," Afghanistan Journal (Graz) 2/4, 1975, pp. 123-34. R. and N. Tapper, "Eat This, It'll Do You a Power of Good: Food and Commensality among Durrani Pashtuns," American Ethnologist 13/1, 1986, pp. 6279. B. Wannell, "Bread Making in Afghanistan," Afghanistan (London) 10, 1989, pp. 22-23.

\section{(Nancy Hatch Dupree)}

COON, CARLETON STEVENS (b. Wakefield, Massachusetts, 23 June 1904, d. Gloucester, Massachusetts, 4 June 1981), American anthropologist and educator. Coon was educated at Harvard University, where he took his Ph.D. degree in anthropology in 1928 and also taught anthropology from 1927 to 1948 . Between 1925 and 1934 he conducted fieldwork in North Africa, the Balkans, Ethiopia, and Arabia. In 1948 he left Harvard to become professor of anthropology at the University of Pennsylvania and curator of general ethnology at the University Museum. Beginning in the next year, he conducted excavations in Persia, Aghanistan, and Syria.

Coon published numerous general works on anthropology (Chapple and Coon, 1942; Coon, 1948, 1954, 1971 ) and on the ethnography of Islamic peoples from Morocco to Afghanistan (1931, 1951a). His interest in the origin of races $(1962,1965)$ and fossil man led him to undertake in 1949 the first systematic search for Paleolithic remains in Persia (Coon, 1951b). During 